Artigo

\title{
Condições Atmosféricas que Favorecem a Concentração de Poluentes no Sul do Brasil
}

\author{
Miriam de Oliveira Baumbach $^{1}$ id, Nisia Brusche ${ }^{2}$ \\ ${ }^{1}$ Centro Federal de Educação Tecnológica de Minas Gerais, Belo Horizonte, MG, Brazil. \\ ${ }^{2}$ Centro de Ciências Computacionais, Universidade Federal do Rio Grande, Rio Grande, \\ RS Brazil.
}

Recebido em 2 de Agosto de 2017 - Aceito em 27 de Agosto de 2017.

\begin{abstract}
Resumo
Pretendeu-se identificar e classificar as condições atmosféricas quando concentrações significativas de PTS ocorreram em Rio Grande. Identificou-se 110 casos com concentrações maior que $30 \mu \mathrm{g} \cdot \mathrm{m}^{-3}$, dos quais 53 eram maiores que $75 \mu \mathrm{g} \cdot \mathrm{m}^{-3}$. Os eventos foram agrupados em 8 categorias segundo a similaridade do escoamento do vento e do campo de pressão superficial, através dos campos atmosféricos obtidos nos dados de Reanálise. A maioria destes casos ocorre quando há um sistema de alta pressão estabelecido ao sul, ao norte ou sobre a região, o qual propicia ventos moderados que não favorecem a dispersão dos poluentes. Foram analisados também os dados de temperatura média semanal da superfície do mar. Quando ocorre alta pressão há um fluxo de águas frias vindas do sul, enquanto que nos casos de baixa pressão favorece um fluxo de águas quentes vindas do norte. Foi realizada uma classificação satisfatória das condições atmosféricas que favorecem a concentração de poluentes na cidade, além de identificada uma possível interação oceano-atmosfera com as variações locais de temperatura da superfície do mar. Esta classificação, somada a previsão numérica das condições atmosféricas, pode ser aplicada no alerta à população sobre a possibilidade de concentrações elevadas na região.
\end{abstract}

Palavras-chave: particulado total em suspensão, reanálise, poluição atmosférica

\section{Atmospheric Conditions That Favor Pollutant Concentrations in the South of Brazil}

\begin{abstract}
Significant concentrations of Total Suspended Particulate found in Rio Grande, in some years in the 90's, were identified and their associated atmospheric conditions were applied to create a classification of situations that favor high pollutants' concentrations. A hundred ten cases with concentrations above $30 \mu \mathrm{g} . \mathrm{m}^{-3}$ were detected and 53 out of those had concentrations above $75 \mu \mathrm{g} . \mathrm{m}^{-3}$. Events were grouped into 8 categories according to the similarity of the wind flow and the surface pressure field, based on the atmospheric fields obtained from Reanalysis data. Most cases take place when there is a high-pressure system south of, north of or over the region since it triggers moderate winds which do not enable pollutant dispersion. Data on weekly mean sea surface temperatures were also analyzed. When there is high pressure, there is a flow of cold waters coming from the south whereas, in low-pressure case, there is a flow of hot waters coming from the north. A satisfactory classification of atmospheric conditions that favor pollutant concentration in the city was carried out. An interaction between the ocean and the atmosphere was identified. This classification, along with the numerical weather forecast, may be used to warn population about the possibility of high pollutant concentrations.
\end{abstract}

Keywords: total suspended particulate, reanalysis, atmospheric pollution.

\section{Introduction}

Atmospheric pollution occurs when substances generated by industries, vehicles, thermoelectric power plants and other sources are emitted into the atmosphere in concentrations high enough to cause hazardous effects on human beings, animals and vegetation. One class of air pol-

Autor de correspondência: Miriam de Oliveira Baumbach,miriam.baumbach@gmail.com. 
lutants comprises all particles smaller than $100 \mu \mathrm{m}$ in suspension in the air, and is denominated Total Suspended Particulate (TSP). These particles, mainly their smaller fractions, may cause adverse health effects in people with pulmonary diseases, such as asthma and bronchitis, and may damage vegetation, reduce visibility and contaminate the soil (Seinfeld, 1986). Emissions from motor vehicles are the main agents of degradation of air quality (Teixeira $\mathrm{et}$ al., 2008), but other sources of TSP are industrial emissions, biomass burns, and dust, along with natural sources such as polen, and soil and marine aerosols (Katsoulis, 1995; Fepam, 2010).

Pollutant frequency, duration and concentration are determined by atmospheric processes since atmosphere is the medium through which pollutants propagate. Relations between the pollution levels and meteorological conditions have been investigated all over the world (Kassomenos et al., 1998; Turarioglu et al.; 2005; Bainy et al., 2012; Corrêa e Carvalho, 2012; Santos et al., 2016).

Incecik (1996) analyzed the occurrence of atmospheric types when there is high concentration of sulfur dioxide $\left(\mathrm{SO}_{2}\right)$ and TSP in Istanbul and observed that these episodes tend to occur when there is a high pressure stationary system which causes moderate winds. He also noticed the presence of anticyclones and the passage of cold air masses some days before the episodes, as well as thermal inversions that coincide with the events of high pollutant concentrations. He believes that high $\mathrm{SO}_{2}$ and TSP concentrations may be related to cold periods. Cheng and Lam (1998) have also shown that winter months are more prone to $\mathrm{SO}_{2}$ and TPS concentrations in Hong Kong. In this period, the direction of the wind velocity favors accumulation, as well as higher atmospheric stability.

In Rio Grande, analysis of TSP data showed several episodes in which there is high concentration of this pollutant (Saraiva and Krusche 2002; Baumbach and Krusche, 2006). Saraiva and Krusche (2002) assessed the variation of meteorological factors, such as temperature, pressure, air relative humidity, rainfall and wind velocity and direction, by using data from the Meteorological Station $n^{\circ} 83995$ in
Rio Grande. They started the assessment three days before the episodes and carried it out up to the days with the highest concentrations of TSP in 1990, in 1994 and from 1997 to 1999 . They observed the seasonal variation of the atmospheric conditions when these episodes occurred; in general, the episodes are characterized by increase in pressure, decrease in temperature and relative humidity, little or nonexistent rainfall and light and, usually, northeast winds.

The improvement on particles in suspension measurements allowed for a division in two classes, denominated $\mathrm{PM}_{10}$, for the fraction of particles with a diameter between 2.5 and $10 \mu \mathrm{m}$, and $\mathrm{PM}_{2.5}$, which correspond to the fraction of particles with a diameter of $2.5 \mu \mathrm{m}$ or less. Recent studies show that these two classes behave different than STP under weather conditions during high concentration events. Nevertheless, Sivaramasundaram and Muthusubramanian (2010) present a reasonable correlation between STP and $\mathrm{PM}_{10}$. Therefore, in the review in table 1, we present results for $\mathrm{PM}_{10}$ and $\mathrm{PM}_{2.5}$.

This study aims at identifying and classifying atmospheric conditions when significant TSP concentrations occurred in Rio Grande, by the analysis of atmospheric fields obtained from Reanalysis data collected at the National Center of Environmental Prognoses and at the National Center of Atmospheric Research, in the United States of America.

For the period of study, only TSP was measured regularly by the environmental agency on this region. There is no data on fractionated particulate matter. Thus, available data on TSP were analyzed. Although this group has not been included in the legislation on atmospheric pollution in some countries, the Brazilian legislation still uses this classification in its air quality standards. Such fact justifies and provided the basis for this study.

In the next section, there is a description of the area of study and of the methodology applied to TSP and Reanalysis data. After that, results are shown and discussed; they are satisfactory, by comparison with other recordings of atmospheric conditions which favor pollutant concentration. Conclusions of this study are discussed in the last section.

Tabela 1 - Review of studies of atmospheric conditions associated with high particulate concentrations.

\begin{tabular}{|c|c|c|c|}
\hline Author & Place & Class & Atmospheric Conditions \\
\hline Mok e Hoi & Macau, $\mathrm{CHN}$ & $\mathrm{PM}_{10}$ & $\begin{array}{l}\text { Dry and cold winter monsoons, low pressure and relative humidity and the } \\
\text { weakening and change of the wind direction- caused by tropical cyclones. }\end{array}$ \\
\hline Sanchez-Ccoyllo e Andrade, 1998 & São Paulo, SP & $\mathrm{PM}_{2.5}$ & $\begin{array}{l}\text { Light winds and influence of a high pressure system with low relative humid- } \\
\text { ity and low precipitation. }\end{array}$ \\
\hline Corrêa e Carvalho, 2012 & Rio de Janeiro, RJ & $\mathrm{PM}_{10}$ & $\begin{array}{l}\text { Influence of the Subtropical High Pressure of South Atlantic, light wind, sub- } \\
\text { sidence, clear skies and no rain. }\end{array}$ \\
\hline Bainy et al., 2012 & Pelotas, RS & $\mathrm{PM}_{2.5}$ & Light winds \\
\hline Santos et al., 2016 & Rio de Janeiro, RJ & $\mathrm{PM}_{10}$ & $\begin{array}{l}\text { Influence of the Subtropical High Pressure of South Atlantic, no rain and oc- } \\
\text { currence of thermal inversion in the lower atmosphere. }\end{array}$ \\
\hline
\end{tabular}




\section{Study Area}

Rio Grande is located in the southern coast of Rio Grande do Sul state, in southern Brazil (Fig. 1), with a population of 197,228 (Ibge, 2010). Although a survey on its pollution sources is not available, Rio Grande is designated as the 5th highest industrial pollutant potential in the state by the State Foundation of Economics and Statistics (Martins e Oliveira, 2005). The city houses an industrial park surrounded by bodies of water of shallow depths and variable salinities, which are natural nurseries for diverse species of fish of important commercial value. There are a petroleum refinery; vegetable oil fabrication; nitrogen, phosphate and potassium fertilizer plants as well as oil and petrochemical terminals. These industries move the local economy and are the main source of employment and income of the town. It also has one of the busiest seaports in the country. The Port of Rio Grande receives about 3,000 vessels per year, representing about 270 vessels per day (Porto de Rio Grande, 2017). Finally, according to the state department of transit (Detran, 2017), Rio Grande has a total fleet of 115,499 vehicles.

\section{Data}

Data on TSP concentrations were provided by the Fundação Estadual de Proteção Ambiental Henrique Roessler (FEPAM), which is the state environment agency in charge of monitoring industrial emissions. During the 90's, the agency did not have automatic stations in this region, so there are no data on fractionated particulate matter, such as $\mathrm{PM}_{10}$. TSP Measurements were carried out in three manual monitoring stations of air quality, named Montevideo Station, CEEE station, and CORSAN station, whose locations are shown in Fig. 1. The Montevideo station is located on a square downtown, surrounded by trees and buildings; the CORSAN station is farther away from downtown, in the yard of the local water company, called CORSAN; and the CEEE station is located near the industrial area, in its electrical substation.

Data from 1990, 1994, 1997, 1998 and 1999 were used. These data were collected at least once a week, in a 24-h period, from 10 am to 10 am the next day, by the High Volume Indicator method (Fepam, 2005). As a result, the annual series should be composed by at least 52 samples, but not all of them are complete and some exceed the measurements. Failures happen mainly in summer months. Table 2 shows that about $50 \%$ of the measurements occurred in 1990 and 1994 whereas about $80 \%$ were carried out in 1997, 90\%, in 1998, and more than $100 \%$, in 1999 .

Resolution $\mathrm{n}^{\circ} 3$ issued by the Conselho Nacional de Meio Ambiente (CONAMA), a national environmental protection agency, established two criteria for air quality standards in 1990. Primary pattern are the pollutant concentrations which may affect the population's health when they

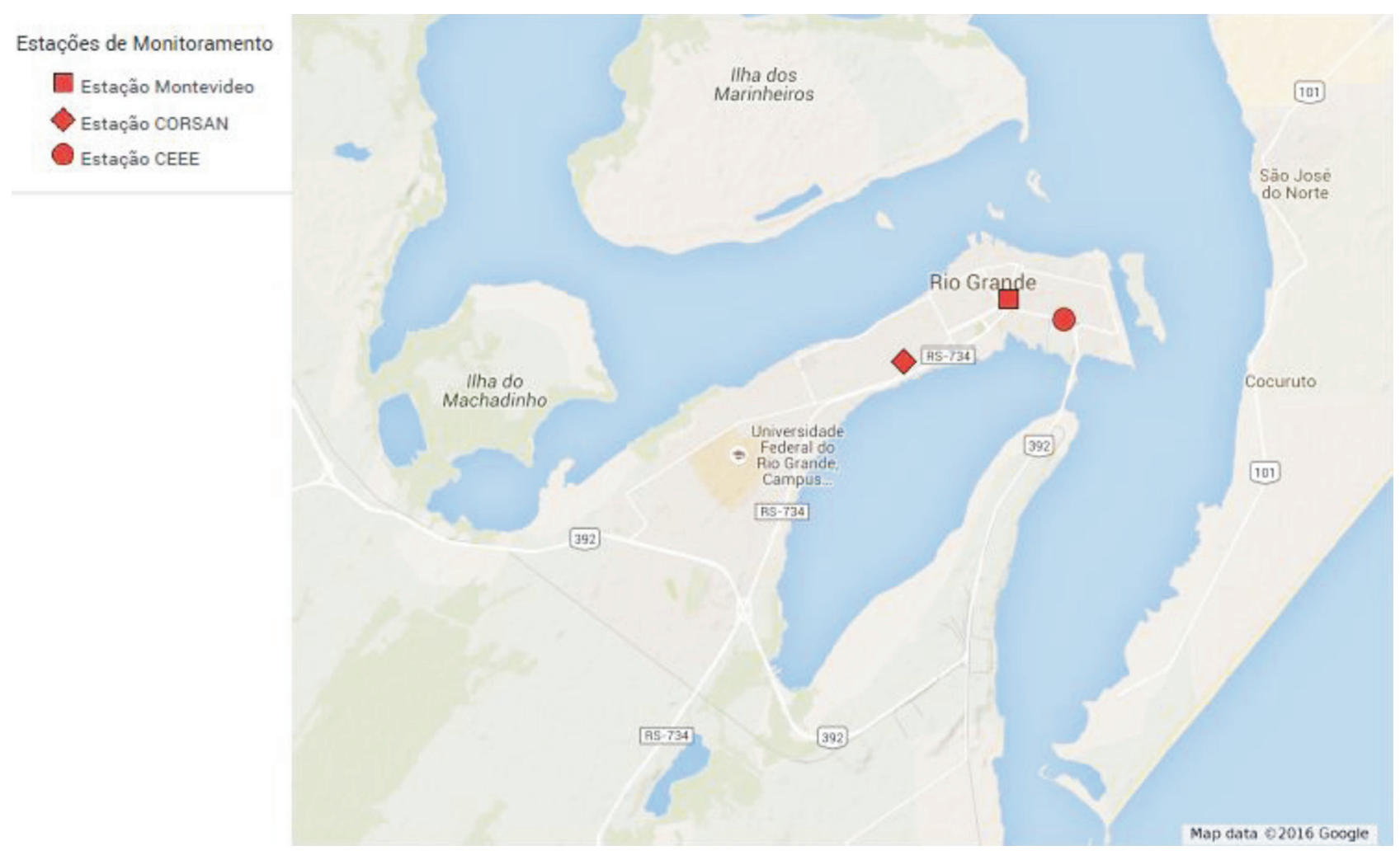

Figura 1 - Location of FEPAM's monitoring stations. Industrial sources are mainly on the left of the channel, on State Road 392. 
Tabela 2 - Number of TSP measurements carried out at FEPAM's three monitoring stations and Percentage of Measurements (PM) that were carried out, in relation to the total number of measurements that should have been carried out in a seven-day interval in 1990, 1994, 1997, 1998, and 1999. The column on the right shows the total number of events with concentrations above $30 \mu \mathrm{g} . \mathrm{m}^{-3}$ in the three stations.

\begin{tabular}{|c|c|c|c|c|c|c|c|}
\hline \multirow[t]{2}{*}{ Year } & \multicolumn{3}{|c|}{ Number of measurements } & \multicolumn{3}{|c|}{$\mathrm{PM}(\%)$} & \multirow[t]{2}{*}{ Number of events } \\
\hline & Montevideo & CEEE & Corsan & Montevideo & CEEE & Corsan & \\
\hline 1990 & 26 & 26 & 25 & 50 & 50 & 48 & 7 \\
\hline 1994 & 26 & 26 & 28 & 50 & 50 & 53 & 15 \\
\hline 1997 & 48 & 42 & 42 & 92 & 80 & 80 & 30 \\
\hline 1998 & 47 & 54 & 42 & 90 & 103 & 80 & 24 \\
\hline 1999 & 55 & 57 & 56 & 105 & 109 & 107 & 34 \\
\hline Total & 202 & 205 & 193 & & & & 110 \\
\hline
\end{tabular}

exceed established limits. Secondary pattern are the pollutant concentrations below which the minimum adverse effect on the population's welfare is found. The primary pattern of TSP concentrations established by Resolution $n^{0} 3$ is $240 \mu \mathrm{g} . \mathrm{m}^{-3}$ while the secondary pattern is $150 \mu \mathrm{g} \cdot \mathrm{m}^{-3}$ (Conama, 1990). Both pattern refer to 24-h measurements and must not exceed more than once a year.

Frequency distributions were constructed for the temporal series and their most frequent values were determined. Two stations (Fig. 2) have more frequent values in the interval which starts at $30 \mu \mathrm{g} . \mathrm{m}^{-3}$. Firstly, a decision was taken to analyze all events whose concentrations were higher than this value, because a larger number of data would make the analysis more adequate from a statistical point of view, although this threshold is low by comparison with CONAMA's pattern. Days on which TSP concentrations were higher than $30 \mu \mathrm{g} \cdot \mathrm{m}^{-3}$ were identified at all stations simultaneously. Secondly, atmospheric data related to the measurement period were selected, $i$. e., at $12 \mathrm{UTC}$ (Universal Time Coordinated) on the day the filter is installed and from 00 UTC and 12 UTC on the day the filter is

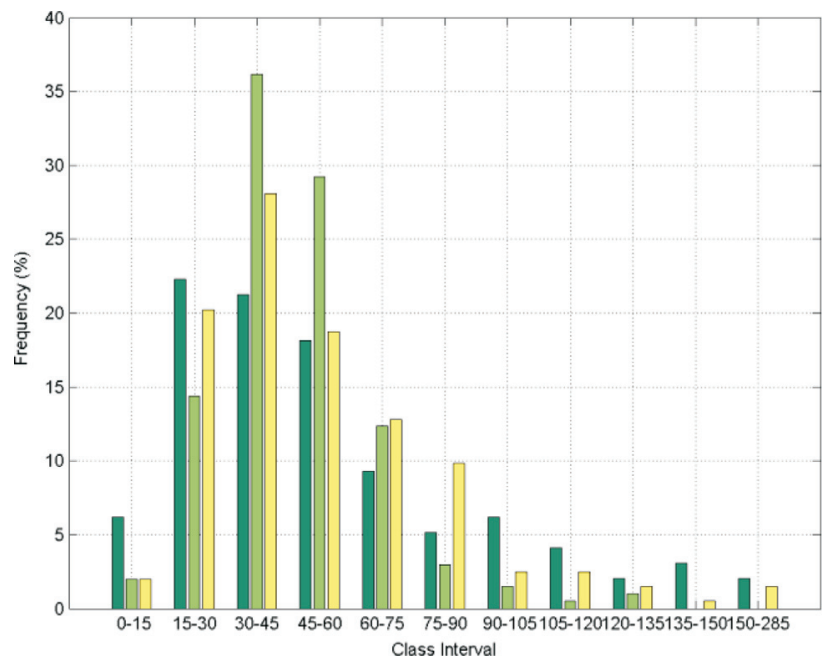

Figura 2 - Frequency distribution of TSP concentrations at the CEEE station (yellow), the Montevideo station (light green) and the CORSAN station (dark green). removed. They correspond to $9 \mathrm{am}, 9 \mathrm{pm}$ and $9 \mathrm{am}$, local time, respectively. Afterwards, events with concentrations above $75 \mu \mathrm{g} . \mathrm{m}^{-3}$ were also analyzed; it corresponds to half the secondary pattern of concentration.

Frequency distributions of TSP concentrations in 1990, 1994, and from 1997 to 1999 at FEPAM's three monitoring stations are shown in Fig. 2. Table 3 shows that, in this period, 193 valid measurements were carried out at the CORSAN station, 202 were conducted at the Montevideo station and 203 were performed at the CEEE station. Since they had small frequencies, class intervals above 150 were grouped in the $150-285 \mu \mathrm{g} \cdot \mathrm{m}^{-3}$ interval. The CEEE station had the highest TSP concentration, i. e., $283 \mu \mathrm{g} . \mathrm{m}^{-3}$. Seven out of 598 measurements carried out in all stations exceeded the secondary pattern established by CONAMA and one exceeded the primary pattern. The relatively low occurrence of extreme events in the four years under analysis may be related to the periodicity of measurements, besides failures in the two first years when, on average, only $50 \%$ of expected measurements/year were carried out.

Reanalysis data on atmospheric fields of surface pressure, temperature, specific humidity, wind velocity and sea temperature was provided by the National Center of Environmental Prediction and the National Center of Atmospheric Research (Kistler et al., 2001). The grid was from $40^{\circ} \mathrm{W}$ to $60^{\circ} \mathrm{W}$ longitude and from $20^{\circ} \mathrm{S}$ to $40^{\circ} \mathrm{S}$ latitude with a distance of 2.5 degrees between points. The use of these data was validated by a previous study carried out by Baumbach and Krusche (2006) who reported the reasonable relation between the Reanalysis data and the data col-

Tabela 3 - Total of valid measurements, concentration average and standard deviation of TSP concentration series at FEPAM's three monitoring stations.

\begin{tabular}{|c|c|c|c|}
\hline $\begin{array}{l}\text { Monitoring } \\
\text { stations }\end{array}$ & $\begin{array}{c}\text { Total of } \\
\text { measurements }\end{array}$ & $\begin{array}{l}\text { Average concentra- } \\
\text { tion }\left(\mu \mathrm{g} \cdot \mathrm{m}^{-3}\right)\end{array}$ & $\begin{array}{c}\text { Concentration SD } \\
\left(\mu \mathrm{g} \cdot \mathrm{m}^{-3}\right)\end{array}$ \\
\hline Corsan & 193 & 56,02 & 2,82 \\
\hline Montevideo & 202 & 46,67 & 1,31 \\
\hline CEEE & 203 & 52,55 & 1,97 \\
\hline
\end{tabular}


lected at the meteorological station no. 83995 , located in Rio Grande.

Eight different categories were created by similarity, visually comparing the superficial pressure and the wind fields. The atmospheric systems associated with them were identified, applying some evidence from temperature and humidity fields, which characterize the air masses in the region. In order to eliminate the seasonal variation that had already been identified by previous studies (Saraiva and Krusche, 2002), the anomaly was calculated by subtracting the monthly mean fields of every case; later, the mean of every group was determined. The four groups with the largest number of cases had their standard variation calculated. Since the sea surface temperature showed low seasonal variation, only the mean fields of all classes and the standard deviation of the four most numerous ones were calculated.

\section{Results}

A hundred ten cases with TSP above $30 \mu \mathrm{g} . \mathrm{m}^{3}$ were identified: $6 \%$ occurred in $1990,14 \%$ in $1994,27 \%$ in $1997,22 \%$ in 1998 and $31 \%$ in 1999 . The number of cases showed a tendency to increase from 1994 to 1999, because there were fewer data on the first years under analysis. Twenty-eight events occurred in summer, 39 in autumn, 16 in winter, and 27 in spring. The smaller number of events in winter may be related to the most frequent wind direction. The measurement stations are to the east of the industries, while the most frequent wind direction in the winter is from the southwest (Krusche et al., 2003).

The days with TSP concentration above $75 \mu \mathrm{g} \cdot \mathrm{m}^{3}$ at one of the stations, at least, were also identified so as to analyze the cases in which TSP concentrations reached the highest levels. Fifty three occurrences were found: 1 in 1990, 7 in 1994, 16 in 1997, 11 in 1998 and 18 in 1999. Due to the same reason previously described, more occurrences were observed in the last years under analysis. This result corroborates what was found in the analysis of TSP occurrences above $30 \mu \mathrm{g} \cdot \mathrm{m}^{3}$, since 43 out of 53 cases, i.e., more than $81 \%$, fit into categories from 1 to 4 . Thirteen cases were observed in class $1 ; 11$ in class $2 ; 9$ in class $3 ; 10$ in class $4 ; 4$ in classes 5 and 6 ; and 1 in classes 7 and 8 . Table 4 summarizes these results.

Class 1 (Fig. 3) consists of 23 events; $48 \%$ occurred in summer. It is characterized by a positive anomaly of pressure southeast of Rio Grande, which generates moderate winds blowing from the east. The temperature has negative anomaly in the continent during the day and homogeneous anomaly close to the mean at night. Specific humidity is characterized by positive anomaly north of Rio Grande in the diurnal fields and a negative one in the nocturnal field (Fig. 4).

Class 2 (Fig. 4) comprises 21 events; 38\% happened in autumn. It is characterized by a center of positive anomaly of pressure east of Rio Grande, which generates moderate winds blowing from the northeast. Associated with the high pressure system passage, there is a positive anomaly of temperature in the southwest. Specific humidity has positive anomaly in the diurnal fields in the northwest; it inverts the signal in the nocturnal field (Fig. 4).

Class 3 (upper row in Fig. 5) has a center of positive pressure anomaly over Rio Grande; it generates light winds and an anticyclonic spin centered over the urban area. Temperature and specific humidity fields behave similarly to the ones observed in class 1 . The mean anomaly of temperature is negative over the continent in the fields of 12 UTC and close to the mean in the field of 00 UTC. The anomaly of specific humidity is positive north of Rio Grande in the diurnal fields whereas it is negative all over the grid in the nocturnal field. Fifty five percent of twenty events in this class occurred in autumn.

Tabela 4 - Classification of the atmospheric situation, C, and seasonal variation of the occurrences with TSP concentrations above $30 \mu \mathrm{g} \cdot \mathrm{m}^{3}$ and $75 \mu \mathrm{g} . \mathrm{m}^{3}$, where S, A, W, S and T denote summer, autumn, winter, spring, winter and total number of cases, respectively. HP and LP stand for high pressure and low pressure. NE, SW, SE and E indicate the wind directions: northeast, southwest, southeast and east. RG stands for Rio Grande.

\begin{tabular}{|c|c|c|c|c|c|c|c|c|c|c|c|}
\hline \multirow[t]{3}{*}{$\mathrm{C}$} & \multirow[t]{3}{*}{ Description } & \multicolumn{10}{|c|}{ Occurrences } \\
\hline & & \multicolumn{2}{|c|}{$\mathrm{S}$} & \multicolumn{2}{|c|}{ A } & \multicolumn{2}{|c|}{ W } & \multicolumn{2}{|c|}{$\mathrm{P}$} & \multicolumn{2}{|c|}{$\mathrm{T}$} \\
\hline & & $>30$ & $>75$ & $>30$ & $>75$ & $>30$ & $>75$ & $>30$ & $>75$ & $>30$ & $>75$ \\
\hline 1 & $\mathrm{HP}$ at SE of RG E winds & 11 & 6 & 2 & 1 & 2 & 1 & 8 & 5 & 23 & 13 \\
\hline 2 & $\mathrm{HP}$ to the $\mathrm{E}$ and $\mathrm{NE}$ winds & 4 & 2 & 8 & 2 & 3 & 3 & 6 & 4 & 21 & 11 \\
\hline 3 & HP over RG & 0 & 0 & 11 & 2 & 5 & 4 & 4 & 3 & 20 & 9 \\
\hline 4 & Setting up of HP & 2 & 1 & 9 & 6 & 4 & 2 & 1 & 1 & 16 & 10 \\
\hline 5 & Cold frontal system passge & 2 & 0 & 2 & 1 & 1 & 1 & 4 & 2 & 9 & 4 \\
\hline 6 & HP over RG SW winds & 2 & 1 & 5 & 2 & 1 & 1 & 0 & 0 & 8 & 4 \\
\hline 7 & Setting up of LP over RG & 5 & 1 & 1 & 0 & 0 & 0 & 1 & 0 & 7 & 1 \\
\hline \multirow[t]{2}{*}{8} & LP system passage & 2 & 0 & 0 & 0 & 0 & 0 & 2 & 1 & 4 & 1 \\
\hline & Total & 28 & 11 & 39 & 14 & 16 & 12 & 27 & 16 & 110 & 53 \\
\hline
\end{tabular}



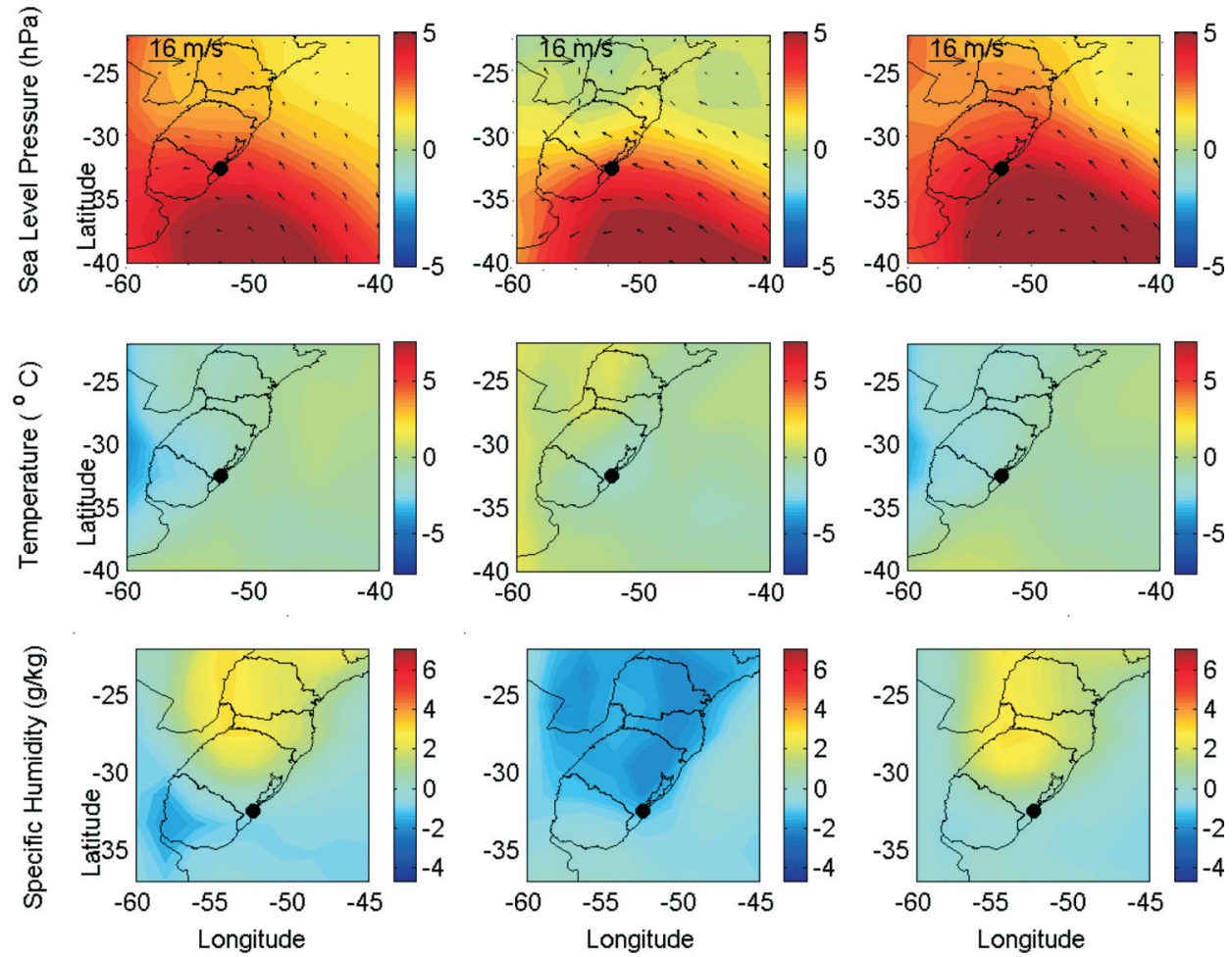

Figura 3 - Mean fields for class 1. Latitudes are represented in the abscissa and longitudes, in the ordinate. The left column corresponds to fields of 12 UTC on the day the filter was installed whereas the middle and right columns represent fields of 00 and 12 UTC on the day the filter was removed. The upper row shows pressure fields at the sea level $(\mathrm{hPa})$ and wind fields. The middle row shows temperature fields $\left({ }^{\circ} \mathrm{C}\right)$, and the bottom row depicts fields of specific humidity $\left(\mathrm{g}_{\text {vapor }} \cdot \mathrm{kg}_{\mathrm{air}}^{-1}\right)$. The black dot shows where Rio Grande is located.
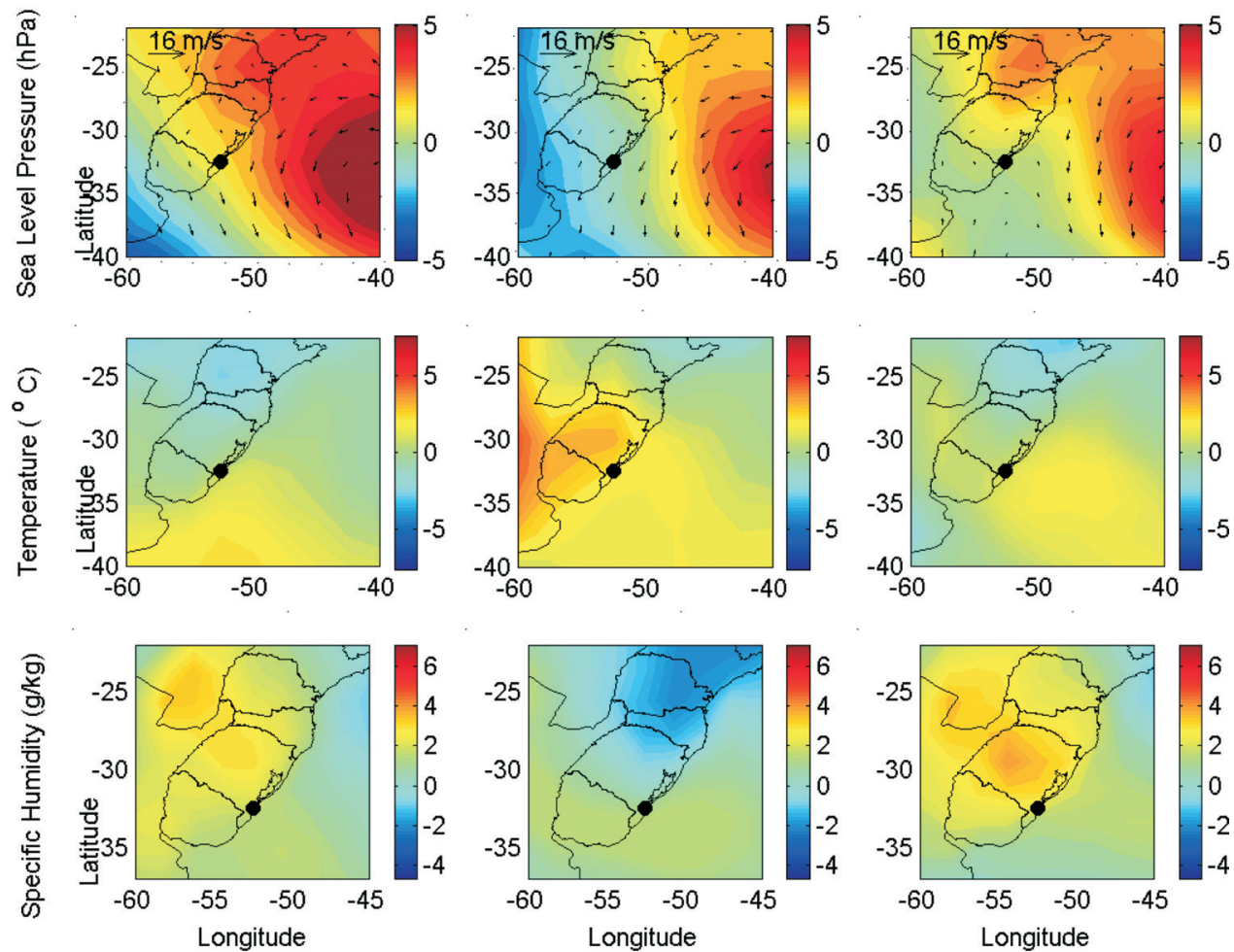

Figura 4 - Mean fields for class 2. Latitudes are represented in the abscissa and longitudes, in the ordinate. The left column corresponds to fields of 12 UTC on the day the filter was installed whereas the middle and right columns represent fields of 00 and 12 UTC on the day the filter was removed. The upper row shows sea level pressure fields $(\mathrm{hPa})$ and wind fields. The middle row shows temperature fields $\left({ }^{\circ} \mathrm{C}\right)$ and the bottom row, the fields of specific humidity $\left(\mathrm{g}_{\text {vapor }} \cdot \mathrm{kg}_{\mathrm{air}}{ }^{-1}\right)$. The black dot shows where Rio Grande city is located. 

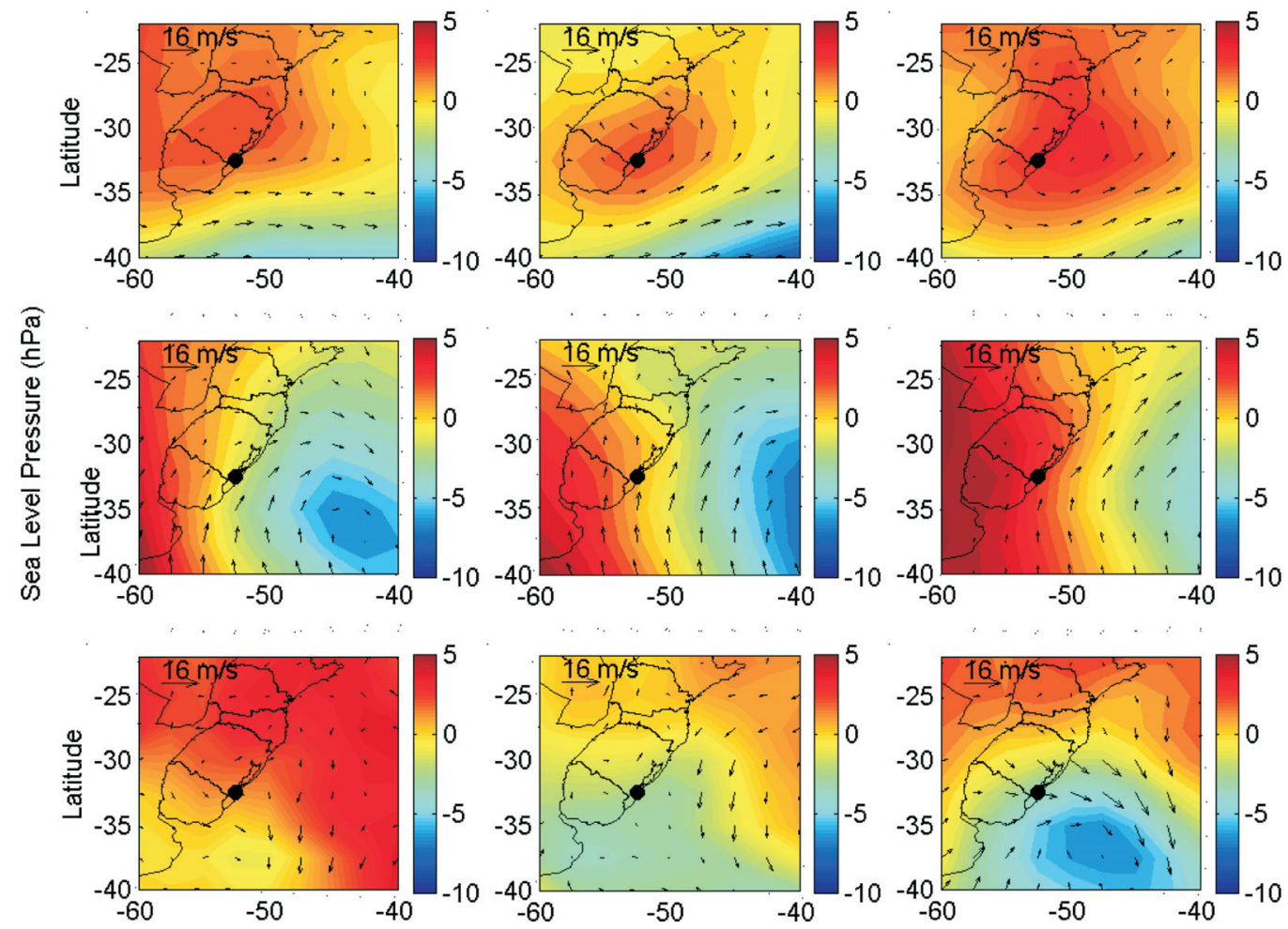

Figura 5 - Mean fields of sea level pressure (hPa) and wind. Latitudes are represented in the abscissa and longitudes, in the ordinate. The left column corresponds to fields of 12 UTC on the day the filter was installed whereas the middle and right columns represent fields of 00 and 12:00 UTC on the day the filter was removed. The upper row represents class 3 , the middle row shows class 4 and the bottom row represents class 5 . The black dot shows where Rio Grande cit is located.

Class 4 (middle row in Fig. 5) comprises 16 cases; $56 \%$ occurred in autumn. This class is characterized by the dislocation of a center of negative anomaly of pressure east of Rio Grande and the establishment of another one of positive anomaly over the city. It is accompanied by negative anomalies of temperature and specific humidity in the southeast.

The mean field in class 5 (bottom row in Fig. 5) shows the dislocation of a center of positive anomaly of pressure caused by a frontal system and wind convergence. This process leads to an increase in temperature and specific humidity, a fact that can be observed due to the positive anomaly. This class comprises 9 events; $44 \%$ occurred in spring.

Class 6 (upper row in Fig. 6) is characterized by the passage of a center of negative anomaly of pressure southeast of Rio Grande and by the establishment of a system of positive anomaly of pressure over the city, which generates winds blowing from the southeast. Negative anomalies of temperature and specific humidity in the west accompanied the entrance of high pressure. In this class, $63 \%$ of 8 cases occurred in autumn.

Seven cases comprise class 7 (middle row in Fig. 6), which shows the establishment of a center of negative anomaly of pressure. The nocturnal field of temperature has a southeastern flow of positive anomaly whereas the other fields keep close to the mean. Specific humidity has positive anomaly north of Rio Grande in the diurnal fields, and a negative one in the nocturnal fields. Seventy two percent of the cases occurred in summer.

Class 8 (bottom line in Fig. 6) shows the passage of a system of negative anomalies of pressure south of Rio Grande with winds blowing from the southwest. The temperature fields show positive anomalies dislocating with the low pressure system and negative anomalies in the west. It is also observed in the specific humidity. All four events in this class are equally distributed in summer and spring.

The analysis of the standard deviation of the classes with the largest number of cases shows that the data on pressure vary more in the southern part of the region of study. As expected, data on temperature and specific humidity have larger variation in the continent and smaller variation over the ocean, because it has higher specific heat capacity, as shown in Fig. 7.

The weekly mean fields of the sea surface temperature were analyzed according to the previously described methodology in order to identify the influence of the ocean temperature on the intensity of the high pressure systems. In classes 1,2,3, and 4, which are under the influence of a high pressure system, there is a flow of cold water coming from the south. Class 5, which is characterized by low pressure and high temperature associated with the passage of the cold front, has a flow of warm waters coming from the north, similar to what happens to classes 6,7, and 8. In these classes, the low atmospheric pressure is associated with a 

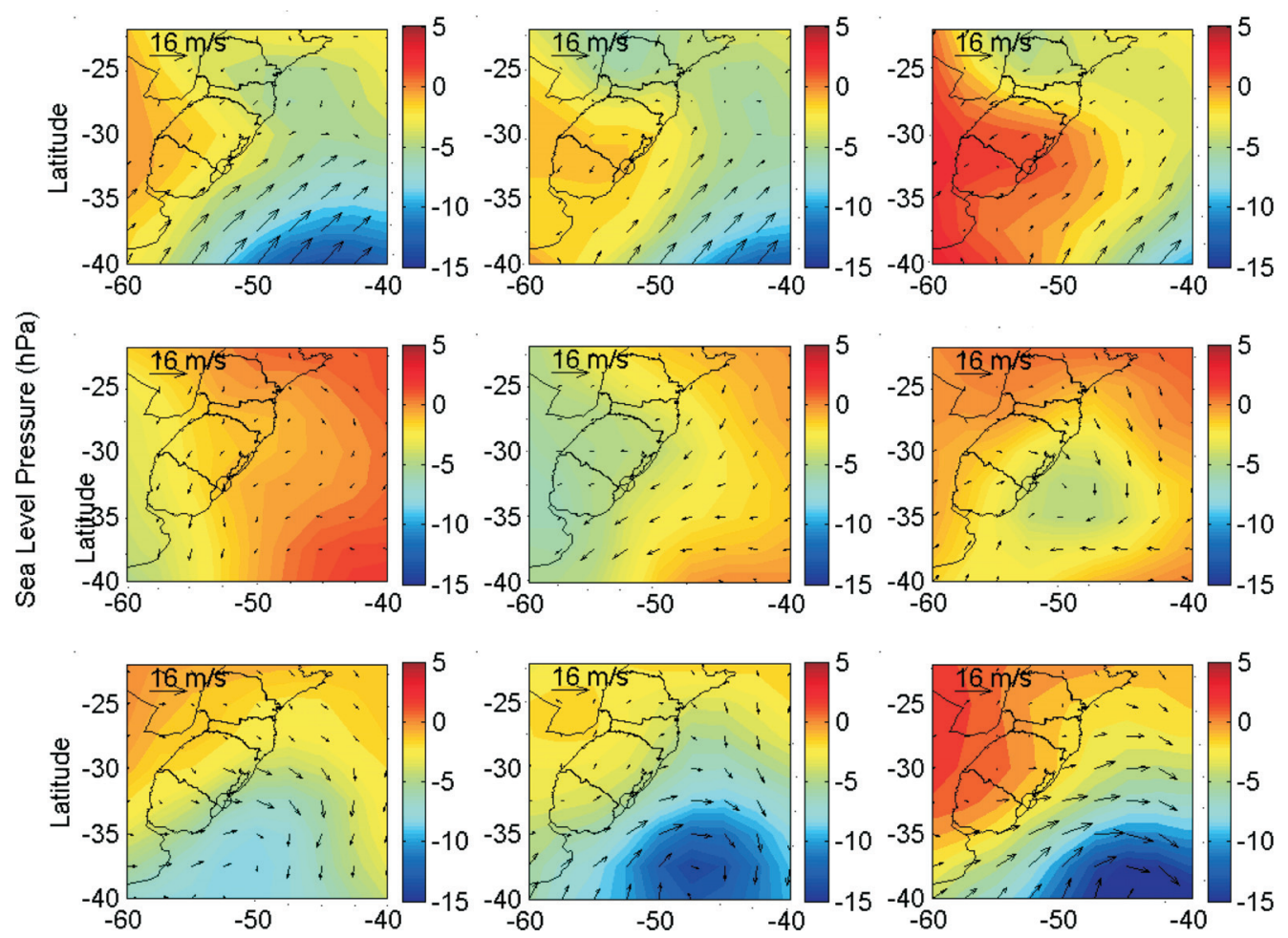

Figura 6 - Mean fields of sea level pressure (hPa) and winds. Latitudes are represented in the abscissa and longitudes, in the ordinate. The left column corresponds to fields of 12 UTC on the day the filter was installed and the middle and right columns represent fields of 00 and 12 UTC on the day the filter was removed. The upper row represents class 6 , the middle row shows class 7 and the bottom row represents class 8 . The black dot shows where Rio Grande is located.
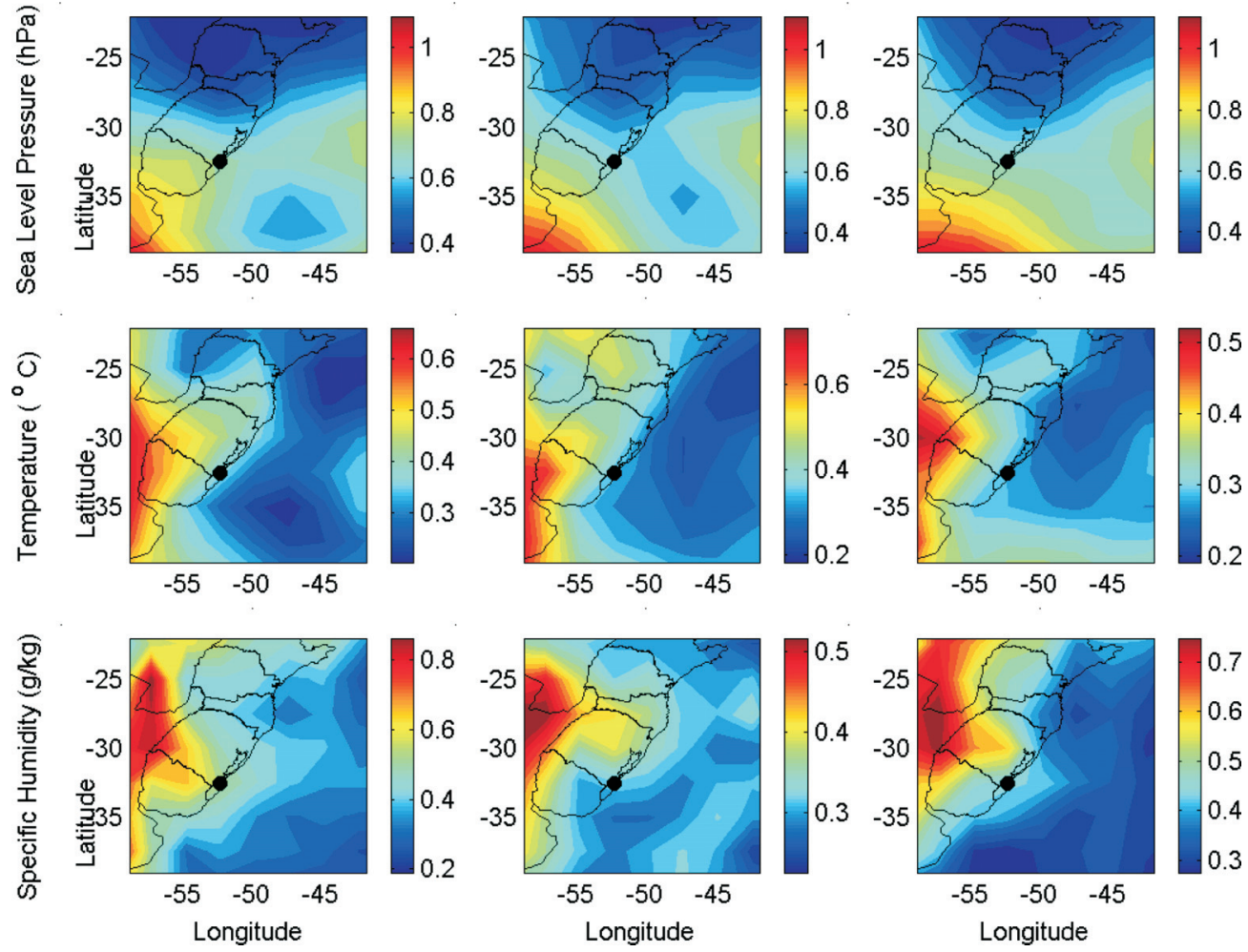

Figura 7 - Standard deviation of class 1 fields. Latitudes are represented in the abscissa and longitudes, in the ordinate. The left column corresponds to fields of 12 UTC on the day the filter was installed and the middle and right columns represent fields of 00 and 12 UTC on the day the filter was removed. The upper row shows the anomaly of sea level pressure $(\mathrm{hPa})$ and wind fields. The middle row represents the anomalies of temperature $\left({ }^{\circ} \mathrm{C}\right)$ and the bottom row shows the anomaly fields of specific humidity $\left(\mathrm{g}_{\mathrm{vapor}} \cdot \mathrm{kg}_{\mathrm{air}}{ }^{-1}\right)$. The black dot shows where Rio Grande is located. 

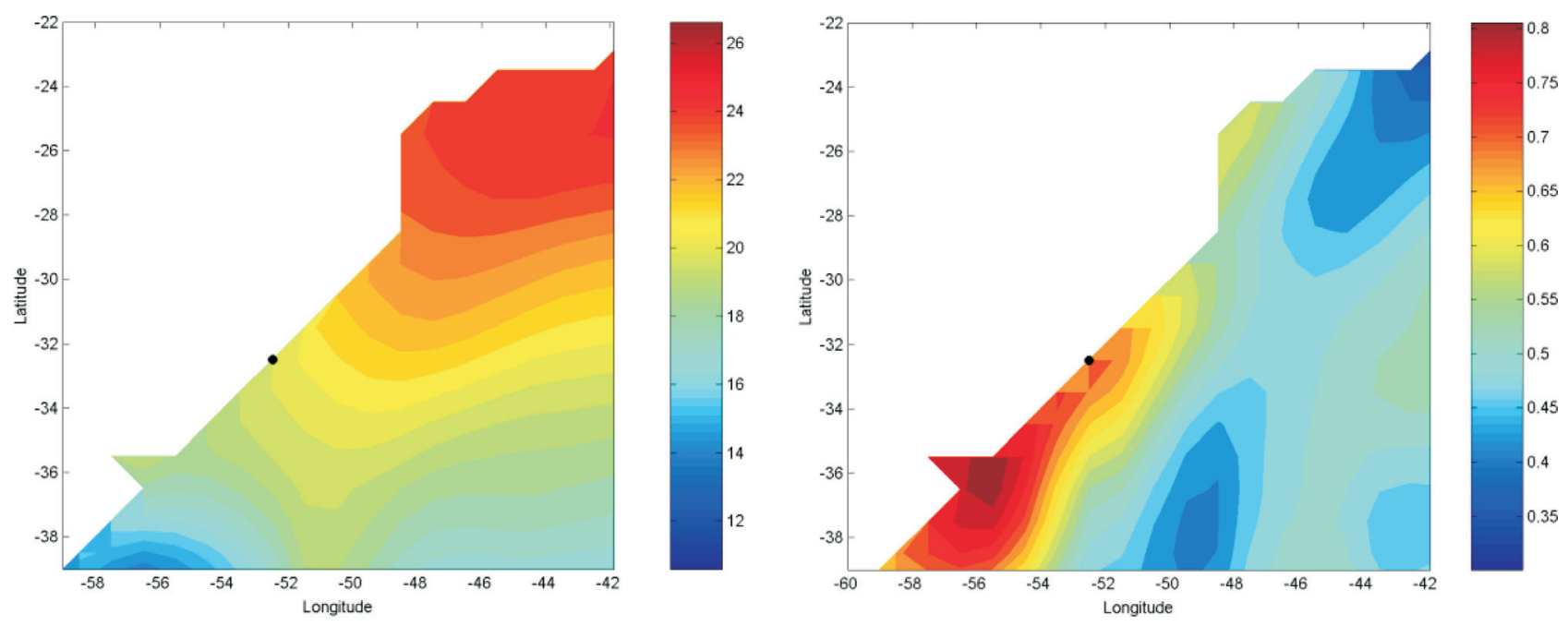

Figura 8 - Weekly mean Sea Surface Temperature fields for class 1. Latitudes are represented in the abscissa and longitudes, in the ordinate. The first column corresponds to mean fields in the week of the events and the second column corresponds to the standard deviation of those fields. The black dot represents Rio Grande.

flow of high sea surface temperature. The standard deviation of the sea surface temperature indicates that, for all classes except class 8 , a larger variation in the region of fresh water discharge coming from the La Plata River occurs, probably due to the frontal rains that precede the establishment of the anticyclone. In case 8, the largest variation occurs in the Santos Basin. The mean of the sea surface temperature and the standard deviation of these fields are shown in Fig. 8.

The first four classes (Figs. 3, 4 and 5), which represent $72.7 \%$ of all cases under analysis, have high pressure atmospheric systems passing through or over the study area. Katsoulis (1996), Incecik (1996), Wai and Tanner (2005) and Santos et al. (2016) also observed these characteristics in their studies. Besides, Santos et al. (2016) have recently shown that, in Rio de Janeiro, episodes of high $\mathrm{PM}_{10}$ concentration occur when the conditions are clear sky, light winds and lack of rain, under the influence of the subtropical anticyclone in the South Atlantic. In their study, Wai and Tanner (2005) also observed that the passage of cold fronts favors the accumulation of pollutants, in agreement with evidence found by this study in class 5 (Fig. 4), which comprises $8.1 \%$ of cases. The three classes (Fig. 6) with the smallest number of cases of high TSP concentration totaled $17.2 \%$ of the cases under study. They are characterized by the passage of low pressure centers southeast of or above Rio Grande, as observed by Mok and Hoi (2005).

\section{Conclusions}

Most events of high TSP concentration are characterized by the passage of mobile polar anticyclones over the region, or south or north of the area, and consequently, in dry and cold weather. The establishment of high pressure and light winds keeps the pollutants close to the surface, preventing them from dispersing towards higher levels.

Results are satisfactory, even though the data on TSP concentration used by this study was collected on a day per week, because the results agree with similar studies carried out in many other regions with data measure at lower frequency.

Reanalysis data were useful to construct the classification of the atmospheric conditions that favor high concentration of pollutants in Rio Grande. Furthermore, a probable ocean-atmosphere interaction with the local variations in the sea surface temperature was identified.

This classification may be applied to forecast when high concentrations will occur, along with numerical forecast which provides superficial fields of pressure and winds. The results might be used for planning of the atmospheric emission and population's warning.

The city needs an automatic station to provide daily data on TSP concentration and other data on the particulate, such as $\mathrm{PM}_{10}, \mathrm{PM}_{2,5}, \mathrm{PM}_{2,0}, \mathrm{NO}_{\mathrm{x}}, \mathrm{SO}_{2}$ and $\mathrm{O}_{3}$. The most meaningful variation of the results found in this analysis is likely to be attributed to the small number of cases in each class. A larger database would enable to carry out a more elaborate objective study in order to establish a more reliable pattern.

\section{Acknowledgments}

The authors would like to thank the Fundação de Amparo à Pesquisa do Estado do Rio Grande do Sul for granting a scholarship throughout part of the research, the Fundação Estadual de Proteção Ambiental Henrique Roessler for providing data and NCAR-NCEP for the Reanalysis Project. They also thank Michelle S. Reboita and Anderson Spolavori for helping with data conversion. 


\section{References}

BAUMBACH, M.; KRUSCHE, N. Classification of atmospheric conditions facilitating high concentrations of pollutants in Rio Grande, Brazil. In: 8th International Conference on Southern Hemisphere, 2006, Foz de Iguaçu, PR, v. 1. p. 89-92, 2006.

BAINY, B.; COLARES, G.; SOARES, F.; SZCZEPANIAK, R.F.; BORK, C.; GAMARO, D.G. Análise da concentração de material particulado no centro de Pelotas, RS, para verão e outono de 2012 e condições meteorológicas associadas. In: XVII Congresso Brasileiro de Meteorologia, 2012, Gramado - RS. Resumos do XVII Congresso Brasileiro de Meteorologia, 2012.

CHENG, S.; LAM, K. An analysis of winds affecting pollution concentration in Hong Kong. Atmos. Envirn., v. 32, n. $14-15$, p. 2559-2567, 1998.

CONAMA - Conselho Nacional do Meio Ambiente. Resolução $\mathbf{n}^{0}$ 003. D.O.U, de 22/08/90, Seção I, p. 15.937-15.939, 1990.

CORRÊA, T.S.; CARVALHO, V.S.B. Análise de condições meteorológicas durante episódios de poluição por material particulado na RMRJ. In: XVII Congresso Brasileiro de Meteorologia, 1998, Gramado - RS. Resumos do XVII Congresso Brasileiro de Meteorologia, 2012.

FEPAM (Fundação Estadual de Proteção Ambiental Henrique Luís Roessler), $1^{\circ}$ Inventário de emissões atmosféricas das fontes móveis do estado do Rio Grande do Sul - Ano base: 2009. Porto Alegre, 2010.

INCECIK, S. Investigation of atmospheric conditions in Istanbul leading to air pollution episodes. Atmos. Environ. v. 30, n. 15, p. 2739-2749, 1996.

KASSOMENOS, P.; FLOCAS, H.A.; LYKOUDIS, S.; PETRAKIS, M. Spatial and temporal characteristics of the relationship between air quality status and mesoscale circulation over an urban Mediterranean basin. Sci. Total Environ., v. 217, n. 1-2, p. 37-57, 1998.

KATSOULIS, B.D. The relationship between synoptic, mesoscale and microscale meteorological parameters during poor air quality events in Athens, Greece. Sci. Total Environ., v. 181, n. 1, p. 13-24, 1996.

KISTLER, R. et al., The NCEP-NCAR 50-Year Reanalysis: monthly means CD- ROM and Documentation. Bull. Amer. Meteor. Soc., v. 82, p. 247-267, 2001.

KRUSCHE, N.; SARAIVA, J.M.B.; REBOITA, M.S. Normais Climatológicas Provisórias de 1991 a 2000 para Rio Grande, RS. v. 1, 84 p, 2003.

MARTINS, C.H.B.; OLIVEIRA, N. Indicadores EconômicoAmbientais na Perspectiva da Sustentabilidade. Porto Alegre : FEE; FEPAM, 2005. Documentos FEE; n. 63.

MOK, K.M.; HOI, K.I., 2005, Effects of meteorological conditions on $\mathrm{PM}_{10}$ concentrations - A study in Macau. Environ. Monit. and Assess. v. 102, p. 201-223, 2005.
SANCHEZ-CCOYLLO, O. R.; ANDRADE, M.F. Características da circulação de grande escala durante episódios de extremos de concentração de poluentes em São Paulo. In: X Congresso Brasileiro de Meteorologia, 1998, Brasília DF. Resumos do X Congresso Brasileiro de Meteorologia, p. 1-5, 1998.

SANTOS, T.C.; CARVALHO, V.S.B.; REBOITA, M.S. Avaliação da influência das condições meteorológicas em dias com altas concentrações de material particulado na Região Metropolitana do Rio de Janeiro. Engenharia Sanitária e Ambiental. v. 21, n. 2, p. 307-313, 2016.

SARAIVA, L.B.; KRUSCHE, N. Análise de situações atmosféricas favoráveis à concentração de poluentes em Rio Grande, RS, através de componentes principais. In: Anais do XII Congresso Brasileiro de Meteorologia, Foz de Iguaçu, PR,.p. 2077-2085, 2002.

SEINFELD, J.H. Atmospheric Chemistry and Physics of Air Pollution. Ed. John Wilwy \& Sons, Canadá. 738 p, 1986.

SIVARAMASUNDARAM, K.; MUTHUSUBRAMANIAN, P. A preliminary assessment of PM10 and TSP concentrations in Tuticorin, India. Air Qual. Atmos. Health, v. 3, n. 2, p. $95-102,2010$.

TEIXEIRA, E.C.; FELTES, S.; SANTANA, E. Estudo das emissões de fontes móveis na região Metropolitana de Porto Alegre-RS. Química Nova, v. 31, n. 2, p. 244-248, 2008.

TURALIOGLU, F.S.; NUHOGLU, A.; BAYRAKTAR, H. Impacts of some meteorological parameters on $\mathrm{SO}_{2}$ and TSP concentrations in Erzurum, Turkey. Chemosphere, v. 59, n. 11, p. 1633-1642, 2005.

WAI K.M.; TANNER, P.A. Extreme particulate levels at a western pacific coastal city: the influence of meteorological factors and the contribution of long-range transport. Journal of Atmos. Chemistry, v. 50, n. 2, p. 103-120, 2005.

\section{Internet Resources}

DETRAN - Departamento de Trânsito - RS. Frota do Rio Grande do Sul. Disponível em: http://www.detran.rs.gov.br/conteudo/27453/frota-do-rs. Acesso em 15 jul 2017.

IBGE, Instituto Brasileiro de Geografia e Estatística, Cidades Rio Grande. Disponível em http://www.cidades.ibge.gov.br/xtras/perfil.php?lang=\&co dmun $=431560 \&$ search=rio-grande-do-sul rio-grande. Acesso em 22 jun. 2016

PORTO DE RIO GRANDE, 2017, Movimentação de embarcações, ano: 2017. Disponível em: http://www.portoriogrande.com.br/site/consultas_estatistic as.php. Acesso em: 15 jul 2017.

This is an Open Access article distributed under the terms of the Creative Commons Attribution Non-Commercial License which permits unrestricted non-commercial use, distribution, and reproduction in any medium provided the original work is properly cited. 